\title{
TAXONOMICAL AND CHOROLOGICAL NOTES 4 (38-58)
}

\author{
János CsikY ${ }^{1 *}$, Dániel Kovács ${ }^{1}$, Judit DemE ${ }^{1}$, Attila TAKÁcs ${ }^{2 *}$, \\ Miklós Óvári ${ }^{3}$, Attila Molnár V. ${ }^{2}$, Ákos MalatinsZKY ${ }^{4}$, \\ József NAGY ${ }^{5}$ and Zoltán BARINA ${ }^{6}$ \\ ${ }^{1}$ University of Pécs, Faculty of Sciences, Institute of Biology, Department of Ecology, \\ H-7624 Pécs, Ifjúság útja 6.; moon@ttk.pte.hu \\ ${ }^{2}$ Department of Botany, University of Debrecen, \\ H-4032Debrecen, Egyetem tér 1, Hungary; limodorum.abortivum@gmail.com \\ ${ }^{3} \mathrm{H}-8900$ Zalaegerszeg, Gorkij u 1/d; miki58@indamail.hu \\ ${ }^{4}$ Institute of Nature Conservation and Landscape Management, Szent István University, \\ H-2103 Gödöllö, Páter K. u. 1, Hungary; malatinszky.akos@mkk.szie.hu \\ ${ }^{5}$ Faculty of Horticultural Science, Szent István University, \\ H-1118 Budapest, Villányi út 29-43, Hungary; Nagy.Jozsef@kertk.szie.hu \\ ${ }^{6}$ Department of Botany, Hungarian Natural History Museum, \\ H-1431 Budapest,.Pf. 137, Hungary; barina.zoltan@nhmus.hu
}

Csiky, J., Kovács, D., Deme, J., Takács, A., Óvári, M., Molnár V., A., Malatinszky, Á., Nagy, J. \& Barina, Z. (2017): Taxonomical and chorological notes 4 (38-58). - Studia bot. hung. 48(1): 133-144.

\begin{abstract}
The fourth part of the recently launched series includes miscellaneous new records of bryophytes and vascular plants from the territory of the Carpathian Basin and the Balkan Peninsula. New chorological records of four bryophytes and 15 vascular plants are provided here. One native species (Anacamptis laxiflora) is new for the flora of the Republic of Macedonia, Montenegro, and Serbia, and seven species (Aconitum variegatum, Bupleurum affine, Carex atrata, Euphorbia phymatosperma, Knautia ambigua, Pulsatilla vernalis, Silene veselskyi) and one subspecies (Zannichellia palustris subsp. pedunculata) for the flora of Albania. Two introduced species (Euphorbia prostrata, Spartina versicolor) are also newly reported from the territory of Albania and four further species (Corynephorus articulatus, Jurinea consanguinea, Koeleria nitidula, Linum thracicum) are reported for the first time from Albania based on previously collected herbarium specimens. The present occurrence of these four taxa needs recent confirmation. Two native (Buxbaumia aphylla, Dicranum tauricum) and one introduced species (Campylopus introflexus) are newly reported from the territory of the Somogyicum region in Hungary, one from the Mecsek Mts (Nowellia curvifolia), one from the Putnok Hills (Lychnis coronaria) and one (Buxbaumia aphylla) is confirmed with the second and further four records in the Börzsöny Mts.
\end{abstract}

Key words: Apiaceae, Asteraceae, Buxbaumiaceae, Caprifoliaceae, Caryophyllaceae, Cephaloziaceae, Cyperaceae, Dicranaceae, Euphorbiaceae, Linaeceae, Orchidaceae, Poaceae, Ranunculaceae, Zannichelliaceae

\section{INTRODUCTION}

This paper is the fourth part of the series launched in Studia botanica bungarica focusing on the new chorological records, nomenclature, and taxonomy of 
plant species from algae to vascular plants and fungi (BARINA et al. 2015, PAPP et al. 2016, TAKÁcs et al. 2016).

\title{
NEW RECORDS WITH ANNOTATIONS
}

\author{
Bryophytes
}

\section{(38) Buxbaumia aphylla Hedw. (Buxbaumiaceae)}

Hungary, Somogy County, Kelet-Belső-Somogy: Barcs, Juniper Woodland, on acidic sand, by a dirt road beside a pine plantation, $45.981211^{\circ} \mathrm{N}, 17.554778^{\circ} \mathrm{E}, 129 \mathrm{~m}$ [0071.1]; leg. et det. Kovács D., Csiky J. \& Deme J., 31.05.2016 (JPU and photodocumented).

This circumpolar boreal-montane bryophyte (HILL and PRESTON 1998) was considered to be rare in Hungary, but nowadays it is known from several locations in hilly and mountain regions, mainly in acidophilous forest communities, on acidic soil or gravel outcrops. See also below at (39).

Although during the earlier surveys, which were carried out in the Juniper Woodland Landscape Protection District (GALAmbos 1981), this taxon was never found here. In addition, it is the first data from a lowland area in Hungary; therefore this record largely extends the potential occurrences of the species. Its closest localities are found in the Mecsek Mts, more than $40 \mathrm{~km}$ away. Due to the unusual habitat type, the associated vascular plant composition (Aira caryophyllea, Ambrosia artemisiifolia, Campanula rotundifolia agg.., Carex caryophyllea, Fagus sylvatica, Festuca vaginata, Hieracium pilosella, Hieracium umbellatum, Holcus mollis, Hypericum perforatum, Luzula campestris, Peucedanum oreoselinum, Rumex acetosella, Solidago virgaurea, Veronica officinalis, Padus serotina, Quercus robur) greatly differs from the generally known (Boros 1968). During a non-systematic survey, we have detected 50 capsules ( 29 well-developed or mature, 21 dead) and 28 setae in three groups, but presumably with a systematic research more stands could be found.

J. Csiky, D. Kovács and J. Deme

\section{(39) Buxbaumia aphylla Hedw. (Buxbaumiaceae)}

Hungary, Pest County, Börzsöny Mts: Nagybörzsöny, Nagy-Pogányhegy, on a steep slope of a boulder scree, in a small patch of an acidophilous beech forest, on acidic soil $47.938056^{\circ} \mathrm{N}$, 18.888211 ${ }^{\circ}$ E, 540 m [8079.3]; leg.: J. Csiky, P. Erzberger and J. Nagy., det. J. Csiky, 30.10.2015 (JPU and photodocumented). - Hungary, Nógrád County, Börzsöny Mts: Diósjenő, Magas-hegy, in acidophilous beech forest, on acidic soil $47.95280^{\circ} \mathrm{N}, 19.00330^{\circ} \mathrm{E}, 520 \mathrm{~m}$ [8080.1]; leg. et det. J. Nagy, 30.03.2017 (photodocumented). - Hungary, Nógrád County, Börzsöny Mts: near Diósjenő, in acidophilous oak forest, on acidic soil $47.95386^{\circ} \mathrm{N}, 19.01886^{\circ} \mathrm{E}, 380 \mathrm{~m}$ [8080.1]; leg. et det.: J. Nagy, 30.03.2017 (Hb. J. Nagy and photodocumented). - Hungary, Pest County, Börzsöny Mts: Szokolya-Királyrét, Lukács-szállás, in acidophilous beech forest, on acidic soil $47.89927^{\circ} \mathrm{N}$, 
$18.95688^{\circ}$ E, $340 \mathrm{~m}$ [8179.2]; leg. et det. J. Nagy, 01.04.2017 (Hb. J. Nagy and photodocumented). - Hungary, Pest County, Börzsöny Mts: Szokolya, Kecskehát-bérc, in acidophilous oak forest, on acidic soil $47.91830^{\circ} \mathrm{N}, 18.94855^{\circ} \mathrm{E}, 490 \mathrm{~m}$ [8079.4]; leg. et det.: J. Nagy, 15.04.2017 (Hb. J. Nagy and photodocumented).

Buxbaumia aphylla is a circumpolar boreal-montane moss species (HILL and PRESTON 1998) distributed in Europe (Hodgetts 2015). The species is currently registered as a vulnerable (VU) bryophyte in Hungary (PAPP et al. 2010, HodgetTs 2015). See more above at item (38).

Buxbaumia aphylla was firstly discovered by László VAJDA (1966) in the Börzsöny Mts (North Hungarian Mountains). The species was found at a single locality called Sasfészek (Kemence, Pest County) in 09.05.1959 [8079.2]. It has not been reported from the Börzsöny Mts in the last 50 years.

Five new populations (4-25 capsules/locality) were found in the Börzsöny Mts in a short period of time (in 2015 and 2017). Each of them occurred on soil in acidic forest communities. The characteristic associated bryophyte species were Atrichum undulatum, Cephaloziella sp., Dicranella heteromalla, Dicranum scoparium, Diphyscium foliosum, Hypnum cupressiforme, Isothecium alopecuroides, Pogonatum aloides, Pogonatum nanum, Poblia nutans, Polytrichum formosum, Polytrichum juniperinum, Polytrichum piliferum on soil and Grimmia muehlenbeckii, Grimmia ovalis, Hedwigia ciliata var. ciliata on nearby rocks.

Since these habitat types are widespread in the Börzsöny Mts, the Bryophyte Mapping of Hungary project presumably will provide additional information on new locations in the region.

J. Nagy and J. Csiky

(40) Campylopus introflexus (Hedw.) Brid. (Dicranaceae)

Hungary, Somogy County, Kelet-Belső-Somogy: Darány, Juniper Woodland, on acidic sand, close to a path at a forest edge, beside a mixed pine plantation, $45.979197^{\circ} \mathrm{N}, 17.565786^{\circ} \mathrm{E}, 130 \mathrm{~m}$ [0071.1]; leg. Csiky J., Deme J. \& Kovács D., det: Csiky J., 31.05.2016 (JPU).

This bryophyte is the most widespread invasive moss species in Europe. It is invading various habitats in Central Europe, preferably occupying anthropogenic, bare, acidic, and nutrient poor soils. Since it was found firstly in Hungary, it became a widely distributed species and has stable populations (Szücs et al. 2014). The expansion of this suboceanic temperate element (HILL and PRESTON 1998 ) is expected mainly in the subatlantic and submontane regions of the country, but in sites characterised by acidic soils and pine plantations as well.

During the former surveys, $C$. introflexus was noticed neither in the Juniper Woodland of Barcs nor in Belső-Somogy (Somogyicum) (GALAmBos 1981, Szücs et al. 2014). We have found very small patches of some $\mathrm{dm}^{2}$ with vegetative specimens. Locally, the species usually spreads with asexual reproduction 
(fragmentation or propagula), but for long distances, spreading by spores is more important (MIKULÁš KovÁ et al. 2012). The closest localities in the Mecsek Mts are more than $40 \mathrm{~km}$ away, but well developed stands with sporophytes occur there. Since the dominant wind direction is northwest and the stand can be found close to the most frequently used pathway, the population in Darány was more likely initialized by carrying of stem tips rather than spores.

The appearance of an invasive moss in such a unique area, like the Juniper Woodland Landscape Protection District, can cause serious problems on its biodiversity (MEULEN et al. 1987), so the monitoring of the C. introflexus stands is strongly recommended there.

J. Csiky, D. Kovács and J. Deme

\section{(41) Dicranum tauricum Sapjegin (Dicranaceae)}

Hungary, Somogy County, Kelet-Belső-Somogy: Barcs, Juniper Woodland, on an $18 \mathrm{~m}$ long rotten Pinus sylvestris log being $32 \mathrm{~cm}$ in diameter, in an old Quercus robur dominated gallery forest with small Pinus sylvestris plantations, $45.978078^{\circ} \mathrm{N}, 17.541129^{\circ} \mathrm{E}, 128 \mathrm{~m}$ [0071.1]; leg. Csiky J. \& Csikyné R. É., 21.05.2016, det. Csiky J. (JPU and photodocumented).

This native but expansive moss is widespread in Hungary but new for BelsőSomogy (Somogyicum). It usually occurs on bark in the lower part of the trunks in hilly and submountain regions (Szücs et al. 2013), but the largest stands in Hungary can be found on rotten pine logs in the Mecsek Mts (CsI KY et al. 2014). The total coverage of this species on the log in Barcs is $150 \mathrm{~cm}^{2}$. Associated species are typical epixyl taxa: Dicranum montanum, Herzogiella seligeri, Hypnum cupressiforme, Lophocolea heterophylla, Nowellia curvifolia (large fertile patches), Platigyrium repens, and Cladonia spp.

J. Csiky

\section{(42) Nowellia curvifolia (Dicks) Mitt. (Cephaloziaceae)}

Hungary, Baranya County, Mecsek Mts: Komló, Barnakö, over the rocky walls on a rotten Fagus sylvatica log, $46.211843^{\circ} \mathrm{N}, 18.300638^{\circ} \mathrm{E}, 284 \mathrm{~m}$ [9775.4], leg. Erzberger, P. \& Deme J., 28.03.2015, det. Csiky J. (JPU); Pécs (Patacs), Páprágy-völgy, on a $5 \mathrm{~m}$ long rotten Pinus nigra log, $46.08645^{\circ} \mathrm{N}, 18.16712^{\circ} \mathrm{E}, 333 \mathrm{~m}$ [9975.1], leg. et det. Csiky J., 16.06.2016 (JPU and photodocumented).

Nowellia curvifolia is a rare vulnerable (VU) epixyl species in Hungary (PAPP et al. 2010). It is new for the moss flora of the Mecsek Mts (Sopianicum). The closest populations are known from the Juniper Woodland Landscape Protection District (56 km away) in Hungary (Galambos 1981) and in the Papuk Mts (73 $\mathrm{km}$ away) in Croatia (personal observation).

It is worth mentioning that both stands of Nowellia curvifolia were found on rotten wood in the Mecsek Mts, associated with Dicranum tauricum. The first 
stems of the species were discovered in a Dicranum tauricum cushion, during the revision of Dicranum collections of JPU, so complete list of associated species in the case of Barnakő is not available. Associated species in the Páprágy valley (Dicranum scoparium, D. tauricum, Herzogiella seligeri, Hypnum cupressiforme, Lophocolea heterophylla, Nowellia curvifolia, Platigyrium repens, Ptilidium pulcherrimum, Tetraphis pellucida, and Cladonia sp.) were very similar to the species assemblage that was found in Barcs, by Csiky J. and Csikyné R.É. (see above), where Tetraphis pellucida and Aulacomnium androgynum were also present on nearby rotten logs. This composition resembles the Tetraphido-Orthodicranetum stricti Hebrard 1973, a bryophyte association of rotten logs in Central Europe (MARSTAller 1981). These data draw our attention to the significant expansion of Dicranum tauricum, which potentially endangers the populations of rare epixyl mosses and liverworts in Hungary (through rapid colonisation, dense and thick cushions, drought tolerance).

J. Csiky and J. Deme

\section{Vascular plants}

(43) Aconitum variegatum L. (Ranunculaceae)

Albania Kukës county, $c a 1.5 \mathrm{~km}$ SE of village Sylbice, in the valley of stream përroi i Tropojës at the side valley of Lugina e Dyshit; in flush, $42.50705^{\circ} \mathrm{N}, 20.14575^{\circ} \mathrm{E}, 1515 \mathrm{~m}$; leg.: Z. Barina, A. Kovács, G. Puskás \& B. Sárospataki, 08.07.2011, Nr. 19436.

Albania; District of Tropojë (Rrethi i Tropojës), above village Dobërdol, on the $S$ slope of Mt maja e Shpatit $(2205.0 \mathrm{~m})$, along a brooklet, on granite, $42.55052^{\circ} \mathrm{N}, 20.05869^{\circ} \mathrm{E}, 1950 \mathrm{~m}$; Z. Barina, A. Kovács, G. Puskás \& B. Sárospataki, 09.07.2011, Nr. 19519.

Aconitum variegatum is a Central European species, with isolated occurrences in the mountains of S Europe. A few localities are known in the North Central region of Greece (Dimopoulos et al. 2013), in Bulgaria (Assyov and PETrovA 2006), and also in Montenegro (Rohlena 1942).

The known localities in Albania are restricted to the upper valley of Tropojë river, in tall herb vegetation. The related $A$. toxicum occurs in forest communities in the eastern part of Montenegro and S Serbia STEVAnović et al. (1991).

Z. Barina

(44) Anacamptis laxiflora (Lam.) R. M. Bateman, Pridgeon et M. W. Chase (Orchidaceae)

Montenegro, Bar region, near Brijege, close to the public road E80, $42.23898^{\circ} \mathrm{N}, 19.02228^{\circ}$ E, 283 m; leg.: M. Óvári, 09.06.2010 (observed); Montenegro, Budva region, near Buljarica, in wet meadows, $42.18250^{\circ} \mathrm{N}, 18.97060^{\circ} \mathrm{E}, 2 \mathrm{~m}$; leg.: M. Óvári, 09.06.2010 (photodocumented).

Republic of Macedonia, Mogila region, near Vasharejca, close to the public road A3, in tallsedge beds and mesic scrub mosaic, $41.17738^{\circ} \mathrm{N}, 21.39449^{\circ} \mathrm{E}, 603 \mathrm{~m}$; leg.: A. Takács \& A. Molnár V., 14.05.2015 (observed). 
Serbia, Pčinja district, Moravica valley, between Levosoje and Borovac, in wet meadow, $42.41776^{\circ} \mathrm{N}, 21.73639^{\circ} \mathrm{E}, 410 \mathrm{~m}$; leg.: A. Takács \& A. Molnár V., 14.05.2015 (photodocumented).

In the Balkan Peninsula it was so far only known from Albania, Greece, and European part of Turkey (RHAzI et al. 2011, GovaerTs et al. 2015). It was also mentioned from former Yugoslavia (DELFORGE 2006), without listing of present states. Records of „Orchis laxiflora” (e.g. HAYEK 1933: 393.) from the states of former Yugoslavia (incl. Serbia, Montenegro and Macedonia) refer to Anacamptis (Orchis) palustris-elegans aggregate. Members of this group formerly were interpreted in subspecies rank under O. laxiflora (e.g. Soó 1980).

A. Takács, M. Óvári and A. Molnár V.

(45) Bupleurum affine Sadler (Apiaceae)

Albania, Korçë county; in the valley E of village Braçanaj, in dry grassland, on clay, $40.545008^{\circ}$ N, 20.987747 E, 865 m; leg.: Z. Barina, H. Mező \& L. Papp, 16.08.2016, Nr. 30511.

It is an East-Central European species, of dry, open habitats, most frequent in Hungary, Serbia, and Bulgaria, and very scattered elsewhere (SNOGERUP \& SNOGERUP 2001).

The Albanian locality is in the region where many xerophytic and continental species have single occurrence in the country. The species is missing in the adjoining region of Greece (Dimopoulos et al. 2013), and has no records from Kosovo. Further occurrences are expected at most in the same region of Albania.

Z. Barina

(46) Carex atrata L. subsp. aterrima (Hoppe) Hartm. (Cyperaceae)

'Albania: in monte Korab supra Radomir', 1800 and 2400 m; leg.: J. Andrasovszky, 24.08.1917, Nr. BP 456093, BP 249704, BP 250072, BP 456094.

Albania, Dibër county; Korab Mts above village Radomirë, in flush, $41.781894^{\circ}, 20.52638^{\circ} \mathrm{E}$, 2307 m; leg.: Z. Barina, H. Mező \& L. Papp, 22.08.2016, Nr. 30614.

It is a North European species, which occurs in the mountains of C. and $S$ Europe. It is known only in the North Central region of Greece and occurs questionably in the Northern Pindos Mts; however, it has been collected in most of the mountains neighbouring $\mathrm{N}$ and NE Albania (Mt. Žljeb, Mt. Koprivnik, Bjelasica Mts), including the Macedonian part of the Korab Mts (SO 33091).

Though the Korab Mts are one of the most frequently visited area by botanists, the species has not been re-collected after Andrasovszky, and the species is not included in synthetic works. It was found again in a flush in the Korab Mts in 2016, and likely, present in other (seasonally) wet habitats of the mountains.

Z. Barina 
(47) Corynephorus articulatus (Desf.) P. Beauv. (Poaceae)

'Perball shkambit te Kavajes, neper ranishte, 1 m'; leg. M. Demiri \& Palikuqi, TIR

It is widespread in the Mediterranean region eastwards to Iran (STRID 2016). The species is apparently missing in Montenegro, but present in W Greece (Dimopoulos et al. 2013) and S Croatia (Nikolić 2015).

During the revision of the TIR herbarium, one correctly identified specimen was found, which was collected in the maritime sands and sandstone rocks at Kavajë. The occurrence has not been confirmed subsequently. It is new for the flora of Albania, but due to the large-scale urbanisation and destroy of natural coasts around Kavajë and Durrës, the species has likely been extinct.

Z. Barina

(48) Euphorbia phymatosperma Boiss. (Euphorbiaceae)

Albania, Gjirokastër county; Griba Mountains, ca $2.5 \mathrm{~km}$ south of town Tepelenë, between the Bridge Bënçë and the prison of Tepelenë, in the valley of river Bënçë, in limestone gorge, $40.26843^{\circ} \mathrm{N}, 20.00964^{\circ} \mathrm{E}, 162 \mathrm{~m}$; leg.: Z. Barina \& G. Király, 04.05.2005, Nr. 7735

Euphorbia phymatosperma is a species of Western North Africa, the Mediterranean Basin, and the Middle East. It is known in the S Ionian Islands in Greece (FlORA IONICA WorkING Group 2016).

Its single known locality is in the dolomitic area of SW Albania, further occurrences are expected in this region.

Z. Barina

(49) Euphorbia prostrata Aiton (Euphorbiaceae)

Albania, Shkodër county, Qafa e Çelës between villages Vau i Dejës and Gomsiqe, along main road SH5, $42.00340^{\circ} \mathrm{N}, 19.72758^{\circ} \mathrm{E}, 458 \mathrm{~m}$; leg.: A. Molnár V., A. Takács, M. Óvári, T. Nagy, R. Fekete \& É. Biró, 03.07.2015, s.n., BP

Albania, Shkodër county, Velipojë, in pavement gaps, $41.86245^{\circ} \mathrm{N}, 19.42486^{\circ} \mathrm{E}$; leg. B. Pintér, 02.11.2014., s.n., BP

It is a North American species, naturalised in the Mediterranean countries, and present in all regions of Greece (Dimopoulos et al. 2013). It was found in the larger cities of Macedonia (MICEVSKI 1998) and in a few settlements in Montenegro (Pulević 2005).

It is likely that the species has been overlooked in Albania and turned up during the revision of accidentally collected specimens of subgen. Chamaesyce. Actually, two localities are known in urban habitats in the northern part of the country, close to each other, but further occurrences are expected throughout the country.

A. Takács \& Z. Barina 
(50) Jurinea consanguinea DC. (Asteraceae)

'Albania or. In rupestribus calcareis mt. Mali That, inter pag. Pojan et Podgorje, ad opp. Korca'; leg.: P. Jakucs, 16.07.1960, BP 589948.

It is an Eastern Balkan species, distributed eastwards to Kazakhstan.

Similarly to many continental and Eastern Balkan species, J. consanguinea occurs only in the SE part of Albania (cf. Bupleurum affine). As missing in the adjoining parts of Greece and in the single old collection known from Thatë Mts, it is likely an isolated occurrence and one of the westernmost populations of the species. It is new for the flora of Albania; however, a recent confirmation is necessary.

Z. Barina

(51) Knautia ambigua Boiss. et Orph. (Caprifoliaceae)

Albania, Shkodër county, at the foot of Mount Vila, above village Velipojë, in mountain grassland, on limestone, $42.54956^{\circ} \mathrm{N}, 19.62238^{\circ} \mathrm{E}, 1640 \mathrm{~m}$; leg.: Z. Barina, D. Pifkó \& H. Mezö, 03.08.2013, Nr. 23055 .

It is a Balkan species distributed from $N$ Greece to $S$ and W Bulgaria.

It is new for the flora of Albania; the new locality extends the area of the species north-westwards, and extends also its altitudinal range.

Z. Barina

\section{(52) Koeleria nitidula Velen. (Poaceae)}

'Polis, kalkar, 1650 m'; leg.: ?, 10.07.1956, det.: B. Achtarov s.d. (as Koeleria splendens and $K$. glaucovirens), J. Ujhelyi 04.06.1969 (as Koeleria penzesi Ujhelyi), SOM 98574, SOM 98575.

'Guri i Topit 1800 m serpentin'; leg.: ? 28.07.1956, det.: B. Achtarov s.d. (as Koeleria glaucovirens), J. Ujhelyi 03.06 .1969 (as Koeleria penzesi Ujhelyi), SOM 98573

'Montes Albaniae boreali-orientalis inter opp. Prizren et Debra jacentes: in lapidosis graminosis declivium orientalium cacuminis altissimi montes nivales Korab supra dolinam maximam supremam ad pagum Radomir, sol. calc.'; leg.: J. B. Kümmerle, 24.07.1918, det.: J. Ujhelyi (as $K$. penzesii Ujhelyi), BP 19827

Koleleria nitidula is distributed from Hungary to Anatolia with a number of described taxa included.

It is new for the flora of Albania; according to the identifications of Ujhelyi, it occurs in various parts of the country. The distribution of the species in Albania is unknown and needs further studies.

Z. Barina

\section{(53) Linum thracicum Degen (Linaceae)}

Albania, 'Auf dem Berge Pastrik bei Prizren', 1500 m; leg.: O. Behr \& E. Behr, 21.07.1936, BP 546352, BP 672605.

'Albania or. In dumetis decl. or. mt. (Mokra) Mucal, ad margines lacui Ohrid, inter pag. Pogradec et Pishkupat. In ass. Buxo-Cotinetum (A.16-18)'; leg.: P. Jakucs, 16.07.1960, BP 589975 
It is a Balkan species, it has not been reported so far not from Albania.

Z. Barina

(54) Lychnis coronaria (L.) Desr. (Caryophyllaceae)

Hungary, North Hungarian Mts (Északi-középhegység), Putnoki-dombság micro-region, Sajógalgóc, Nagy-Pallag, in a low xerotherm wood dominated by Tatar maple, field maple and downy oak, $48.287805^{\circ} \mathrm{N}, 20.514261^{\circ} \mathrm{E}$; leg. Á. Malatinszky, 25.05 .2013 , s.n. (photodocumented) (7789.1).

Rose campion is widespread across Southern and Central Europe, and has been reported from some countries in the western part of Asia as well. It is a characteristic species of subcontinental and submediterranean xerotherm oak woods (Quercetalia cerris Borhidi 1996) in Hungary. Although this taxon is known from several locations in the North Hungarian Mts, no records were found so far east of the Bükk Mts (KIRÁly 2009), i.e. in the north-eastern areas of Hungary. Its closest localities were published by BERÁNEK (2007) from hilly areas around Ózd (Arló, Hangony, Tarnalelesz). In the herbarium collections of the Hungarian Natural History Museum (BP), its closest occurrence was reported from the Northern Bükk Mts: Varbó (Hulják 1923, BP), while Hazslinszky (without year, BP) registered its location as „Tálya”, which may refer to Andornaktálya, Kistálya, or Nagytálya in the Southern Bükk Mts, or Tállya in the Zemplén Mts. VIRók et al. (2016) consider its former data from the Gömör-Torna Karst as false. Therefore, this record extends the species' known area in Hungary towards the NE direction.

Á. Malatinszky

(55) Pulsatilla vernalis (L.) Mill. (Ranunculaceae)

Albania, Kukës county; Albanian Alps, region Gash, above town Tropojë, on the northern slope of mt. Callumit $(2327.0 \mathrm{~m})$, in mountain grassland, on granite, $42.49750^{\circ} \mathrm{N}, 20.11988^{\circ} \mathrm{E}$, 2054 m; leg.: Z. Barina, G. Lunk, D. Pifkó \& D. Schmidt, 07.06.2009, Nr. 15587.

Pulsatilla vernalis is distributed in N Europe and in the mountains southwards. It is very rare in $S$ Europe and in the Balkans.

It is known in the Albanian Alps (DikLIĆ 1992), but has not been reported previously from the Albanian part of the mountains.

Z. Barina

(56) Silene veselskyi (Janka) H. Neumayer (Caryophyllaceae)

Albania, Elbasan county, Jablanica Mts, on the western ridge of Mt. maja e Strapit (1974 m), c. $5.5 \mathrm{~km}$ south of village Steblevë; on limestone rock, $41.28732^{\circ} \mathrm{N}, 20.47357^{\circ} \mathrm{E}, 1810 \mathrm{~m}$; leg.: Z. Barina, D. Pifkó \& A. Vojtkó, 03.07.2008, Nr. 13871. 
The species is a member of Silene pusilla group described from Steiermark (Austria). It is so far known in lower altitudes of the Alps.

It is new for the flora of Albania. Our new record highly extends the species' distribution to the South and also its altitudinal range.

Z. Barina

\section{(57) Spartina versicolor Fabre (Poaceae)}

Albania, Vlorë county, c. $4 \mathrm{~km} \mathrm{SW}$ of village Dëllinjë, on maritime sand dunes, $40.63339^{\circ} \mathrm{N}$, 19.33048 E, 1 m; leg.: Z. Barina, D. Pifkó \& L. Lőkös, 12.10.2012, Nr. 21998

It is a $\mathrm{N}$ American and/or W Mediterranean species, considered to be a native or invasive species in Europe. According to the recent results, European populations are likely to be derived from an introduction of $S$. patens (BAUMEL et al. 2016). It is widespread in W Europe, and has recently been found also in the eastern part of Greece (Dimopoulos et al. 2013).

It is new for the flora of Albania, further occurrences in the coastal marshes are expected.

Z. Barina

(58) Zannichellia palustris L. subsp. pedunculata (Rchb.) Murb. (Zannichelliaceae)

Albania, Fier county, Marinëz oil field between villages Marinëz and Belinë, in saline puddle, $40.73458^{\circ} \mathrm{N}, 19.66439^{\circ} \mathrm{E}, 13 \mathrm{~m}$; leg.: Z. Barina, D. Pifkó \& G. Somogyi, 06.04.2011, det.: A. Mesterházy, Nr. 18592

Albania; District of Shkodër (Rrethi i Shkodrës), Këneta e Gjeratit (Boksi marsh) near village Lagjja e Re, in marsh, $41.92585^{\circ} \mathrm{N}, 19.43791^{\circ} \mathrm{E}, 0 \mathrm{~m}$; leg.: Z. Barina, 26.05.2010, det.: A. Mesterházy, Nr. 17421a

This subspecies is distributed in most of Europe, but its exact distribution is insufficiently known due to merging it with subsp. palustris.

It is new for the flora of Albania; however, its area in the country is unknown and needs further studies.

Z. Barina

Acknowledgements - Work of Attila Molnár V. was supported by OTKA K108992 grant, work of Zoltán Barina by OTKA 104443 grant, and work of Judit Deme by the ÚNKP-16-2-I. New National Excellence Program of the Ministry of Human Capacities.

Összefoglaló: Jelen közleményünk a korábban megkezdett, regionális jelentőségű előfordulásokat és nevezéktani megjegyzéseket tartalmazó sorozat negyedik része. Ebben a részben négy mohafaj és 15 virágos növény faj adatait ismertetjük. 
Közülük egy őshonos faj (Anacamptis laxiflora) új Macedónia, Montenegró és Szerbia flórájára, hét faj (Aconitum variegatum, Bupleurum affine, Carex atrata subsp. aterrima, Euphorbia phymatosperma, Knautia ambigua, Pulsatilla vernalis, Silene veselskyi) és egy alfaj (Zannichellia palustris subsp. pedunculata) pedig Albánia flórájára. További két faj (Euphorbia prostrata, Spartina versicolor) szintén új Albánia flórájára, ezek ottani megjelenése behurcolás eredménye. Négy további fajt (Corynephorus articulatus, Jurinea consanguinea, Koeleria nitidula, Linum thracicum) szintén elsőként közlünk Albániából herbáriumi anyagok feldolgozásának eredményeként, ezek aktuális előfordulásának igazolása az országban további vizsgálatokat igényel.

Magyarország területén 2 honos (Buxbaumia aphylla, Dicranum tauricum) és egy behurcolt fajt (Campylopus introflexus) jelzünk elsőként Belső-Somogy (Somogyicum) területéröl, egyet a Mecsekből (Nowellia curvifolia) egyet (Lychnis coronaria) a Putnoki-dombság területéröl és egy faj (Buxbaumia aphylla) börzsönyi előfordulását erősítettük meg annak 2. és további négy börzsönyi adatával.

\section{REFERENCES}

Assyov, B. and Petrova, A. (2006): Conspectus of the Bulgarian vascular flora. - Bulgaria Biodiversity Foundation, Sofia, $454 \mathrm{pp}$.

Baumel, A., Rousseau-Gueutin, M., Sapienza-Bianchi, C., Gareil, A., Duong, N., RousSeau, H., Coriton, O., Amirouche, R., Sciandrello, S., Duarte, B., Caçador, I., Castillo J. M. and Ainouche, M. (2016): Spartina versicolor Fabre: Another case of Spartina trans-Atlantic introduction? - Biol. Invasions 18(8): 2123-2135. https://doi.org/10.1007/s10530-016-1128-z

BERÁNEK, Á. (2007): Adatok a Heves-Borsodi-dombság és az Upponyi-hegyhát flórájához I. [Data to the flora of the Heves-Borsod Hills and the Uppony Ridge]. - Kitaibelia 12(1): 66-72.

Boros, Á. (1968): Bryogeographie und Bryoflora Ungarns. - Akadémiai Kiadó, Budapest, 466 pp.

Csiky, J., AtKÁRI, B., Deme, J. and Csikyné RADNAI, É. (2014): Mohaflorisztikai érdekességek a Nyugat-Mecsekből. - Kitaibelia 19(1): 29-38.

Delforge, P. (2006): Orchids of Europe, North Africa and the Middle East. - A\&C Black, London, $285 \mathrm{pp}$.

DikLIć, N. (1992): Pulsatilla. - In: SARIć, M. R. (ed.): The flora of Serbia. Vol. 1. Serbian Academy of the Sciences and the Arts, Belgrade, $429 \mathrm{pp}$.

Dimopoulos, P., Raus, Th., Bergmeier, E., Constantinidis, Th., Iatrou, G., Kokrini, S., Strid, A. and Tzanoudakis, D. (2013): Vascular plants of Greece. An annotated checklist. - Englera 31: 1-372.

FLORA IONICA WORKING GRoup (2016 onwards): Flora Ionica - An inventory of ferns and flowering plants of the Ionian Islands (Greece). - Published at https://floraionica.univie.ac.at (accessed: 19.04 .2017$)$

Galambos, I. (1981): A Barcsi borókás tájvédelmi körzet moha flórája. - Dunántúli Dolgozatok Természettudományi Sorozat 2: 25-42.

Govaerts R., Bernet P., Kratochvil K., Gerlach G., Carr G., Alrich P., Pridgeon A. M., Pfahl J., Campacci M.A., Baptista D. H., Tigges H., Shaw J., Cribb P., George A., Kreuz K. and Wood J. (2015): World Checklist of Orchidaceae. Facilitated by the Royal Botanic Gardens, Kew. - Published on the Internet; http://apps.kew.org/wcsp/ (accessed 25.09.2016)

Hayek, A. (1933): Prodromus florae peninsulae Balcanicae 3. Monocotyledoneae. - Fedde's Repert., Beihefte 30(2): 337-576. 
Hill, M. O. and Preston, C. D. (1998): The geographical relationships of British and Irish bryophytes. - J. Bryol. 20: 127-226.

HodgetTs, N. G. (2015): Checklist and country status of European bryophytes - towards a new Red List for Europe. - Irish Wildlife Manuals, No. 84. National Parks and Wildlife Service, Department of Arts, Heritage and the Gaeltacht, Ireland.

Király, G. (ed.) (2009): Új magyar füvészkönyv. Magyarország hajtásos növényei. Határozókulcsok. - Aggteleki Nemzeti Park Igazgatóság, Jósvafo, 616 p.

Marstaller, R. (1981): Zur Soziologie von Dicranum tauricum Sap. 10. Beitrag zur Moosvegetation Thüringens. - Hercynia N.F. 20(1): 89-98.

Meulen, F. van Der, Hagen, H. van Der and Kruijsen, B. (1987): Campylopus introflexus. Invasion of a moss in Dutch coastal dunes. - Proceedings of the Koninklijke Nederlandse Academie van Wetenschappen. Series C: Biological and Medical Sciences 90: 73-80.

MikulášKové, E., FAJMonovÁ, Z. and HÁJEK, M. (2012): Invasion of central-European habitats by moss Campylopus introflexus. - Preslia 84(4): 863-886.

Ni kolić, T. (2015): Flora Croatica baza podataka. - Prirodoslovno-matematički fakultet, Sveučilište u Zagrebu, http://hirc.botanic.hr/fcd (accessed 19.04.2017)

Papp, B., ErZberger, P., Ódor, P., Hock, Zs., Szövényi, P., SZURdoki, E. and Tóth, Z. (2010): Updated checklist and red list of Hungarian bryophytes. - Studia bot. hung. 41: 31-59.

Rhazi, L., Grillas, P., Rhazi, M., Flanagan, D. and Rankou, H. (2011): Anacamptis laxiflora. - The IUCN red list of threatened species 2011: e.T164122A5733232. (accessed 21.02.2017)

Rohlena, J. (1942): Conspectus Florae Montenegrinae. - Preslia 20-21: 1-506.

Soó, R. (1980): Orchis L. - In: Tutin, T. G., Heywood, V. H., Burges, N. A., Moore, D. M., Valentine, D. H., Walters, S. M. and Webb, D. A. (eds): Flora Europaea. Vol. 5. Cambridge University Press, Cambridge, pp. 337-342.

SNOGERUP, S. \& SNOgerup, B. (2001): Bupleurum L. (Umbelliferae) in Europe 1. The annuals, B. sect. Bupleurum and sect. Aristata. - Willdenowia 31: 205-308.

SzŰCs, P., CsıKy, J. and PAPP, B. (2014): A neophyta Campylopus introflexus (Hedw.) Brid. elterjedése Magyarországon. - Kitaibelia 19(2): 212-219.

Szücs, P., Németh, Cs. and Erzberger, P. (2013): Adatok a Dicranum tauricum Sapjegin hazai elterjedéséhez II. - Bot. Közlem. 100(1-2): 147-154.

Stevanović, V., Niketić, M. and Lakušić, D. (1991): Chorological additions to the flora of eastern Yugoslavia. - Flora Mediterranea 1: 121-142.

Strid, A. (2016): Atlas of the Aegean Flora, Part 2. - Englera 33: 1-878.

TAKÁcs, A., Baráth, K., Csiky, J., Csikyné, R. É., Király, G., Nagy, T., Papp, V., SChmidt, D., TAMÁsI, B. and BARINA, Z. (2016): Taxonomical and chorological notes 3 (28-37). - Studia bot. hung. 47(2): 345-357. https://doi.org/10.17110/studbot.2016.47.2.345

VAJDA, L. (1966): A Börzsöny hegység mohaflórája - Fragm. Bot. 4: 79-100.

ViróK, V., FARKAS, R., FARKAS, T., ŠUVADA, R. and VoJTKó, A. (2016): A Gömör-Tornai-karszt flórája. Enumeráció. [Flora of the Gömör-Torna Karst. Enumeration]. ANP füzetek XIV. Aggteleki Nemzeti Park Igazgatóság, Jósvafő, 100 pp. 